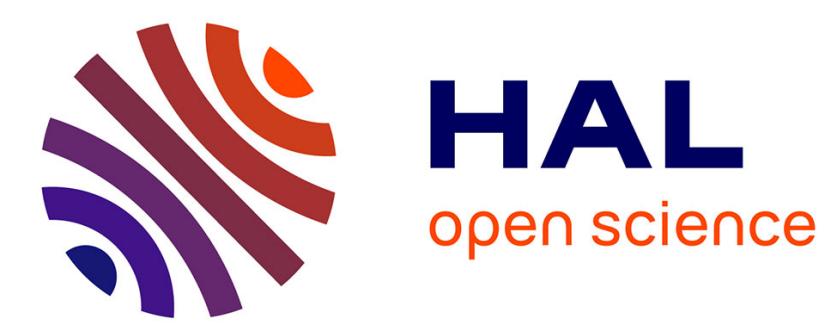

\title{
CORROSION OF CHEMICALLY VAPOUR DEPOSITED TITANIUM CARBIDE ON AN INERT SUBSTRATE
}

A. Delblanc Bauer, J.-O. Carlsson

\section{- To cite this version:}

A. Delblanc Bauer, J.-O. Carlsson. CORROSION OF CHEMICALLY VAPOUR DEPOSITED TITANIUM CARBIDE ON AN INERT SUBSTRATE. Journal de Physique IV Proceedings, 1991, 02 (C2), pp.C2-641-C2-648. 10.1051/jp4:1991277 • jpa-00249867

\section{HAL Id: jpa-00249867 https://hal.science/jpa-00249867}

Submitted on 1 Jan 1991

HAL is a multi-disciplinary open access archive for the deposit and dissemination of scientific research documents, whether they are published or not. The documents may come from teaching and research institutions in France or abroad, or from public or private research centers.
L'archive ouverte pluridisciplinaire HAL, est destinée au dépôt et à la diffusion de documents scientifiques de niveau recherche, publiés ou non, émanant des établissements d'enseignement et de recherche français ou étrangers, des laboratoires publics ou privés. 
Colloque C2, suppl. au Journal de Physique II, Vol. 1, septembre 1991

\title{
CORROSION OF CHEMICALLY VAPOUR DEPOSITED TITANIUM CARBIDE ON AN INERT SUBSTRATE
}

\author{
A. DELBLANC BAUER and J.-O. CARLSSON
}

Thin Film and Surface Chemistry Group, Department of Inorganic Chemistry, University of Uppsala, Box 531, s-751 21 Uppsala, Sweden

\begin{abstract}
The corrosion properties of chemically vapour deposited titanium carbide (TiC) have been studied. Any contribution to the corrosion current from the substrate was avoided by using an inert substrate.

The $\mathrm{TiC}$ was deposited onto substrates of $\mathrm{Al}_{2} \mathrm{O}_{3}$ from a gas mixture containing $\mathrm{TiCl}_{4}$, $\mathrm{CH}_{4}$ and $\mathrm{H}_{2}$ at temperatures between $1020^{\circ} \mathrm{C}$ and $1080^{\circ} \mathrm{C}$. Differences in film thickness and morphology were measured for samples deposited at different temperatures and gas flows. Film thicknesses varied between 0.5 and $1.5 \mu \mathrm{m}$ and grain sizes between 0.1 and $0.8 \mu \mathrm{m}$.

Anodic polarization curves were registered in $1 \mathrm{M}$ hydrochloric acid $(\mathrm{HCl}) . \mathrm{HCl}$ of a lower concentration did not activate the samples. The corrosion potentials of the samples were used as starting points for the polarization curves. Films deposited on polished $\mathrm{Al}_{2} \mathrm{O}_{3}$ at $1020^{\circ} \mathrm{C}$ reached stable potentials of $250 \mathrm{mV}$ (vs. SCE) after one hour. Films deposited onto unpolished substrates had lower values of corrosion potentials $(-100$ to $0 \mathrm{mV}$ VS. SCE ) which reached stability after about three hours. It is suggested that the passivating film on TiC, deposited on polished substrates, achieved a higher protective quality in the solution, due to self-healing. The passivating film on TiC, deposited on unpolished substrates, on the other hand, did not succeed to reach this high quality.

Anodic polarization curves for the different films showed only slight differences. The curves showed two passivation peaks at 800 and $1900 \mathrm{mV}$ (VS. SCE), respectively. An extremely high oxygen overpotential $(>5 \mathrm{~V}$ ) and a poor tendency to transpassive corrosion ( $<6 \mathrm{~V}$ vs SCE) were indicated by the curves.
\end{abstract}

\section{INTRODUCTION}

Titanium carbide thin films are used for many technical applications. Cutting and punching tools and high wear bearings coated with $\mathrm{TiC}$ have been used because of its high hardness. Films of $\mathrm{TiC}$ have also found use as redox electrodes on various substrates and as adhesion improving interlayers. TiC deposition for corrosion protection has been used in the chemical processing industry and in waste water treatment plants $/ 1 \%$.

Increasing effort has been made to optimize the properties of deposited (CVD or PVD) films by varying deposition parameters /2,3/. Much work has been done to determine the mechanical properties of TiC films /4,5/ and some investigations have also been made on their corrosion properties $/ 6 /$. There is always a possibility, however, that the substrate contributes to the corrosion behaviour and thus reliable corrosion data on the film itself can not be measured. However, such data can be obtained by depositing the film on an inert substrate. This has previously been done for TiC deposited onto quartz substrates by activated reactive evaporation $/ 7 /$. In this work the inherent corrosion properties of CVD TiC is reported. 


\section{EXPERIMENTAL}

Films of TiC were deposited onto both unpolished and polished polycrystalline substrates of $\mathrm{Al}_{2} \mathrm{O}_{3}$ $(-99.5 \%)$ (see table 1). Polishing was done with diamond paste $(15 \mu \mathrm{m})$. Prior to the deposition all the samples were cleaned in an ultrasonic bath with freon. The $\mathrm{Al}_{2} \mathrm{O}_{3}$ substrates were then loaded into a hot wall CVD reactor and, during the heating of the furnace, hydrogen $(99.9997 \%)$ was allowed to flow over them. Deposition took place at 1020 to $1080^{\circ} \mathrm{C}$ and a total pressure of 50 torr ( see table 1). When reaction temperature was reached, the gas mixture containing $9 \%$ methane $(99.9995 \%), 6 \% \mathrm{TiCl}_{4}(99.999 \%)$ and $85 \% \mathrm{H}_{2}(99.9997 \%)$ was allowed to flow through the reactor for one to two hours.

When the desired reaction time had passed the gas flows and furnace were shut off and only hydrogen was allowed to flow through the system during cooling. Upon reaching room temperature, the hydrogen flow was turned off and argon (99.9997\%) was admitted into the reactor while removing the samples.

Table 1. CVD parameters for the three batches.

\begin{tabular}{ccccc}
\hline Batch name & $\begin{array}{c}\text { Temp. } \\
{ }^{\circ} \mathrm{C}\end{array}$ & $\begin{array}{c}\text { Gas flow velocity } \\
\text { sccm }\end{array}$ & $\begin{array}{c}\text { Dep. time } \\
h\end{array}$ & Polished substrates \\
\hline A & 1080 & 200 & 1 & None \\
B & 1020 & 200 & 2 & None \\
C & 1020 & 100 & 2 & All \\
\hline
\end{tabular}

Phase content and texture coefficients were determined with X-ray diffractometry (Philips PW 1710). From experimental values of lattice parameter vs. carbon content $/ 8 /$, the carbon content in the films could be estimated. The morphology of the samples were studied in a scanning electron microscope (SEM, JEOL-840). One sample from each experiment was then cut off and the film thickness measured in the SEM. Film thicknesses were also calculated from quantitative analysis with X-ray fluorescence spectroscopy (XRFS).

The samples were glued onto copper cylinders with silver glue to create an electric contact between the sample and the rotating electrode and cold mounted in an epoxy resin (Struers epofix), so that only the sample surface could be exposed to the electrolyte. Before the corrosion testing took place the samples were cleaned with acetone in an ultrasonic bath.

The electrolytes were prepared from concentrated $\mathrm{HCl}$ of analytical grade and deionized water. The resulting solution was deaerated by one hour of water aspiration followed by nitrogen purge during the corrosion measurements. The corrosion cell was thermostatted to $24^{\circ} \mathrm{C}$. The samples could not be activated in $0.1 \mathrm{M} \mathrm{HCl}$. However, in $1 \mathrm{M} \mathrm{HCl}$ the samples were activated. With a PAR 273 potentiostat the corrosion potential of each sample was recorded for three hours. It had then reached stability. The anodic polarization curve was now recorded up to $6 \mathrm{~V}$ ( $\mathrm{Vs}$. the saturated calomel electrode (SCE)), with a scanning rate of $0.1 \mathrm{mV}$ per second and the speed of the rotating electrode being $3000 \mathrm{rpm}$.

After the corrosion measurements, the epoxy and the copper cylinders were removed from the samples. The samples were analysed again with X-ray diffraction, SEM and XRFS.

\section{RESULTS}

The $X$-ray diffractograms from the uncorroded samples showed peaks from TiC (Khaembraevit, JCPDS-file 32-1383) and $\mathrm{Al}_{2} \mathrm{O}_{3}$ (Corundum, JCPDS-file 10-173). Texture coefficients (TC) were calculated by using equation 1 for the different reflecting angles of $\mathrm{TiC}$. 


$$
T C_{h k l}=\frac{I_{h k l}^{\prime} / I_{h k l}}{\frac{1}{n} \sum_{i=1}^{n}\left(I_{h_{i} k_{i} l_{i}}^{\prime} / I_{h_{i} k_{i} l_{i}}\right)}
$$

$l '$ is the measured intensity, $I$ is the calculated intensity, hkl are the indices for the reflections and $n$ is the number of reflecting angles.

The [200] direction dominated the $A$ and $B$ batches $\left(T_{200}=1.3\right)$, whereas the [113] direction dominated the $\mathrm{C}$ batch $\left(\mathrm{TC}_{113}=1.6\right)$.

Table 2 shows measured values of grain sizes and film thicknesses for the samples. Grain sizes varied between 0.1 and $0.8 \mu \mathrm{m}$, the lowest values being for the $C$ batch and the highest for the $A$ batch. Film thicknesses of uncorroded samples vary between 0.5 and $1.5 \mu \mathrm{m}$.

Table 2. Grain sizes and film thicknesses of the batches

\begin{tabular}{|c|c|c|c|}
\hline Batch & Grain size/ $\mu \mathrm{m}$ & $\begin{array}{l}\text { Film th } \\
\text { SEM }\end{array}$ & 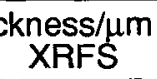 \\
\hline$A$ & $0.5-0.8$ & $1-2$ & $1-1.5$ \\
\hline B & $0.2-0.6$ & $1-2$ & $0.8-1$ \\
\hline$C$ & $0.1-0.5$ & $0.5-1$ & $0.5-0.9$ \\
\hline
\end{tabular}

The open circuit potential was measured for three hours and stable potential values in the range -100 to $350 \mathrm{mV}$ (vs. SCE) were reached. The lower values represent the A and $B$ batches which in some cases reached an unstable higher potential value after about 1.5 hours and which then rapidly dropped. Potential time curves are shown in fig. 1.

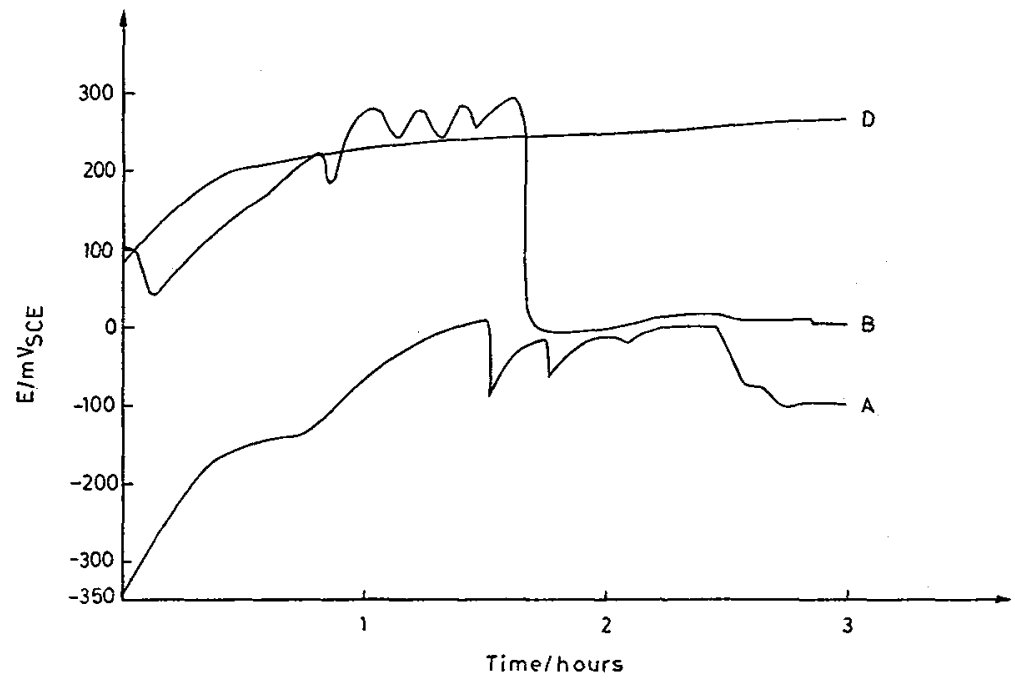

Fig.1 Measured potential vs. time (at zero current). 
Surfaces of uncorroded samples were grey and TiC on polished substrates had a metallic lustre. The surfaces of corroded samples were dark grey. For the $C$ samples, the corroded film was very thin and had a light grey colour. SEM of corroded samples displayed attacked areas in grain boundaries and that sharp, triangular grains in $\mathrm{A}$ and $\mathrm{B}$ are rounded.

The anodic polarization curves of the three different batches are shown in fig.2. Two active peaks at 800 and $1800 \mathrm{mV}$ (vs. SCE), respectively appear. Critical current density $\left(i_{c c}\right)$ for the first active peak ranges from 30 to $570 \mu \mathrm{A} \cdot \mathrm{cm}^{-2}$ and passive current density (i ) between 2 and $47 \mu \mathrm{A} \cdot \mathrm{cm}^{-2}$. For the second peak $i_{c}$ is 1 to $7 \mathrm{~mA} \cdot \mathrm{cm}^{-2}$ and $i_{p}$ varies between 25 and $190 \mu \mathrm{A} \cdot \mathrm{cm}^{-2}$. After the second passive region the current density does not increase again but decreases or remains constant at least up to $6 \mathrm{~V}$ (vs. SCE), where the recording was ended, and no transpassive corrosion occurred. No oxygen evolution could be detected, indicating that the oxygen overpotential was higher than 5 volts.

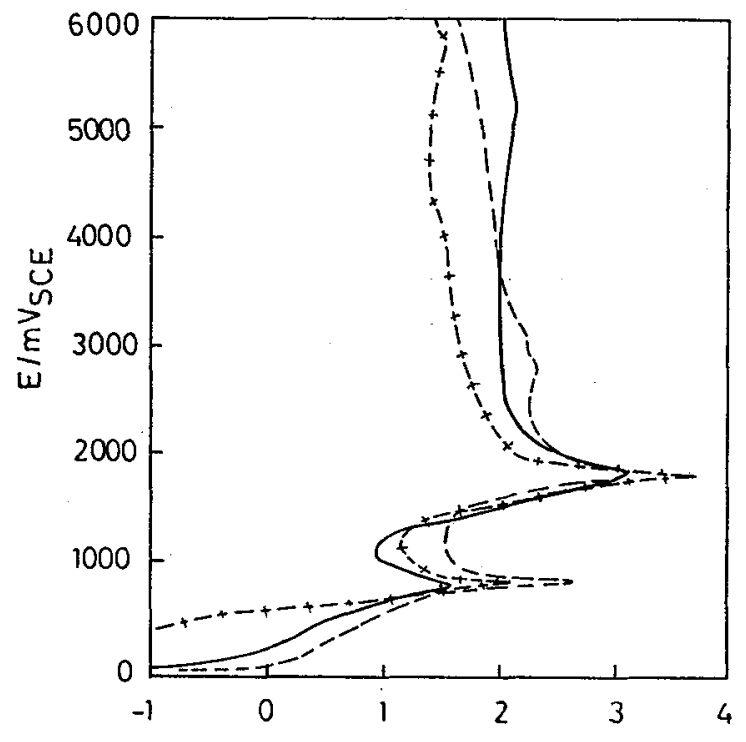

$\log i / \mu \mathrm{A} \mathrm{cm}^{-2}$

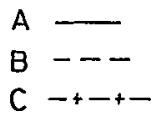

Fig.2 Anodic polarization curves.

$X$-ray diffractograms for corroded samples showed only peaks of TiC and $\mathrm{Al}_{2} \mathrm{O}_{3}$. No peaks from any corrosion products could be found.

\section{DISCUSSION}

Variations in deposition parameters related to batch characteristics and corrosion behaviour. 
Samples prepared in the $C$ batch yielded the thinnest films. For the $C$ batch, a lower gas flow velocity than in the $B$ batch was employed. Furthermore, polished substrates were used in the $C$ batch and not in the B batch. Theoretically one would expect a higher deposition rate with a lower gas flow. However, Lindström and Amberg /9/ have shown that, for CVD of TiC and at sufficient supply of reactants, the deposition rate is not influenced by the total gas flow rate. The only remaining explanation is that the deposition rate decreases with the polishing of a substrate. On an unpolished substrate there will be a higher density of nucleation sites, which might explain the thicker films obtained in batch $B$.

No clear distinction of corrosion behaviour between the samples can be seen in the polarization curves. Measurement of corrosion potential vs. time, however, shows a decided difference between the $\mathrm{C}$ batch and the two other batches. As can be seen in fig.1, potential values of $\mathrm{C}$ samples reach 200 to $250 \mathrm{mV}$ (vs. SCE) after about one hour and remain stable for the rest of the recording time. Potential values of $A$ and $B$ samples, on the other hand, either remain low with slight variations or reach a higher value only to make a sudden drop to the lower values where they remain.

It has been suggested in earlier work $/ 7,10$ / that spontaneous passivation of TiC occurs even at very low oxygen concentrations. The reason for the high open circuit potential could therefore be that the cathodic reaction is a sum of $\mathrm{O}_{2}$-reduction and hydrogen evolution. The easiest explanation for the higher value of the steady state potential for the $\mathrm{C}$ batch is higher oxygen concentration in these solutions. The solutions have, however, been treated identically in all experiments and there is still an apparent difference in corrosion potential between the $C$ batch on one hand and the $A$ and $B$ batches on the other.

A rise in corrosion potential is the result of either increased anodic polarization or decreased cathodic polarization. (Decreased cathodic polarization would be the case in a more oxygen-rich solution.) When a passivating film is formed on the surface it forms a barrier through which reactants diffuse with difficulty. Evans measured the potential of a metal with a discontinuous oxide film $/ 11 /$. His experiments showed that breakdown of the film resulted in potential drops whereas a self-healing film increased the potential. In another work /12/ Bannister and Evans conclude that a high final potential, at zero current, indicates immunity from attack. It should be noted that the corrosion potential discussed here, gives no information about the corrosion current or corrosion rate. Two plausible explanations as to why the samples show differences in corrosion potentials will be given here.

It has been documented that specific solutions etch different crystal planes at different rates /13/. The preferred orientations vary between the batches (see "Results") and this might give differences in the rate at which they passivate.

Another, perhaps more significant, explanation for these discrepancies is the difference in surface smoothness due to polishing of the substrates. A deposit with a smooth surface will, upon oxidation, form a stronger and continuous protective layer. The higher values of steady state potential for the $C$ samples, as well as the shorter time of getting there, could thus be explained by the formation of better protecting films.

\section{Comparison with Pourbaix diagram.}

It may be fruitful to discuss the anodic polarization curves in relation to a Pourbaix diagram. The Pourbaix diagram for $\mathrm{TiC}$ can be studied in fig.3. The dotted line in the diagram indicates $\mathrm{pH} 0$. According to mixed potential theory the corrosion potential should lie between the reversible potentials of $\mathrm{H}^{+} / \mathrm{H}_{2}$ and $\mathrm{TiC} / \mathrm{Ti}^{3+}$ ( -244 and $-420 \mathrm{mV}$ vs. SCE, respectively). The recorded values of 10 to $350 \mathrm{mV}$ (vs. SCE), being higher than the reversible potential of $\mathrm{H}^{+} / \mathrm{H}_{2}$, indicates residual oxygen in the electrolyte and spontaneous passivation. According to the diagram the stable phase at the first active peak is $\mathrm{TiO}_{2} \cdot \mathrm{H}_{2} \mathrm{O}$ and the reaction here should be one of the following:

$$
\begin{aligned}
& \mathrm{TiC}+4 \mathrm{H}_{2} \mathrm{O} \Leftrightarrow \mathrm{TiO}_{2} \cdot \mathrm{H}_{2} \mathrm{O}+\mathrm{CO}(\mathrm{g})+6 \mathrm{H}^{+}+6 \mathrm{e}^{-} \\
& \mathrm{TiC}+5 \mathrm{H}_{2} \mathrm{O} \Leftrightarrow \mathrm{TiO}_{2} \cdot \mathrm{H}_{2} \mathrm{O}+\mathrm{CO}_{2}(\mathrm{~g})+8 \mathrm{H}^{+}+8 e^{-}
\end{aligned}
$$

When the potential is increased and the current once again rises, the oxidation of $\mathrm{TiO}_{2} \cdot \mathrm{H}_{2} \mathrm{O}$ to $\mathrm{TiO}_{3} \cdot 2 \mathrm{H}_{2} \mathrm{O}$ takes place according to equation (4):

$$
\mathrm{TiO}_{2} \cdot \mathrm{H}_{2} \mathrm{O}+2 \mathrm{H}_{2} \mathrm{O} \Leftrightarrow \mathrm{TiO}_{3} \cdot 2 \mathrm{H}_{2} \mathrm{O}+2 \mathrm{H}^{+}+2 \mathrm{e}^{-}
$$




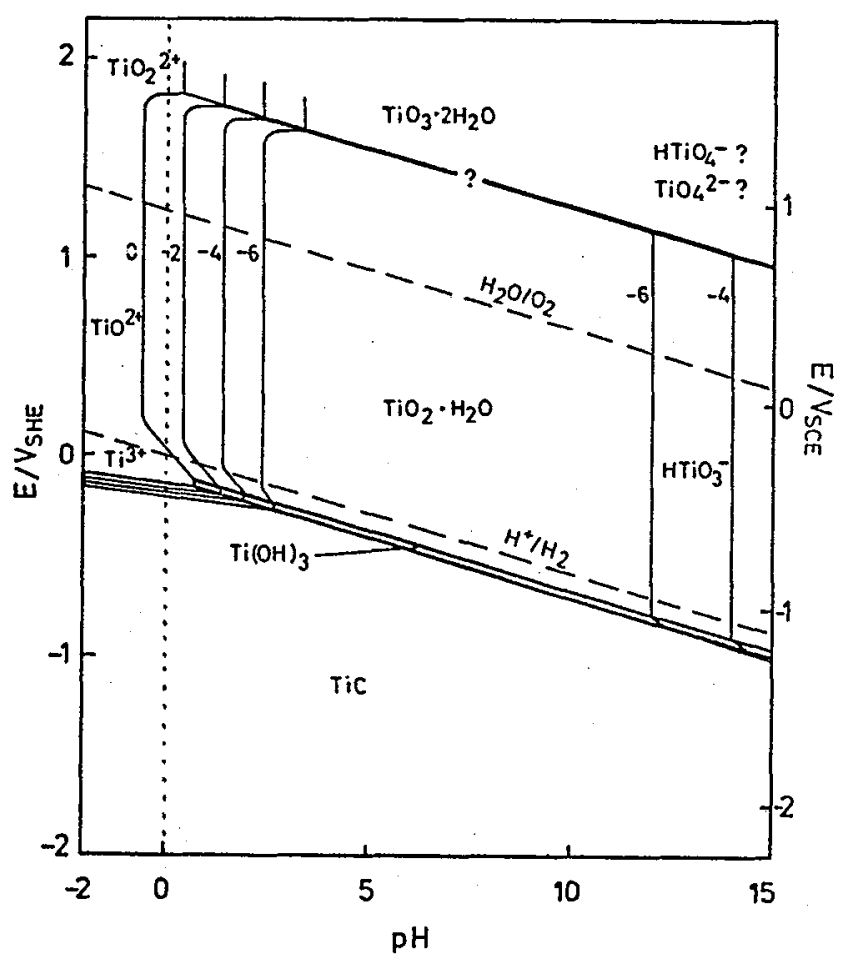

Fig.3 Pourbaix diagram for TiC (from Beverskog and Carlsson /14/)

\section{Related works}

Hintermann and Cowling have made a thorough investigation of the corrosion products of CVD $\mathrm{TiC}$ in sulphuric acid $/ 15 \%$. The TiC was deposited onto steel discs which were then removed and polarization experiments were conducted on the remaining flakes of TiC (which contained up to four percent each of iron and chromium). The recorded polarization curve of $\mathrm{TiC}$ in $2 \mathrm{M} \mathrm{H}_{2} \mathrm{SO}_{4}$ shows an active peak at about $1050 \mathrm{mV}$ (Vs. SHE) corresponding to $830 \mathrm{mV}$ (vs. SCE), which is in good agreement with this work. At $1800 \mathrm{mV}$ (VS. SHE) further dissolution begins but no peak value can be determined since the recording ends at $2000 \mathrm{mV}$ (VS. SHE).

Corrosion products at the first peak were determined in galvanostatic, coulometric and rotating ring disc electrode experiments. The authors concluded that the dissolution of TiC produced $\mathrm{TiO}_{2} \cdot \mathrm{H}_{2} \mathrm{O}$, with $\mathrm{Ti}^{3+}$ as an unstable intermediate, and $\mathrm{CO}$, which was either desorbed or oxidized to $\mathrm{CO}_{2}$. Above $970 \mathrm{mV}$ (vs. SHE) $\mathrm{CO}$ is said to be the stable carbon species. Presuming that corrosion products are the same in $\mathrm{H}_{2} \mathrm{SO}_{4}$ and $\mathrm{HCl}$, equation 2, above, should be the valid one for the present experiment. For the second current rise it was assumed that $\mathrm{TiO}_{2}^{2+}$ is formed which can not be true for our case, except as an intermediate reaction, since passivity is once again reached.

Morancho et al. /10/ registered anodic polarization curves of polycrystalline sintered TiC. They reported a corrosion potential in $5 \mathrm{~N}$ sulphuric acid solutions of $420 \mathrm{mV}$ (vs. SHE) corresponding to $180 \mathrm{mV}$ (vs. SCE) which is almost the mean value for the present work. Polarization curves showed one peak at $1150 \mathrm{mV}$ ( $v s$. SHE) and a broad one at 2200 to $2600 \mathrm{mV}$ ( $v \mathrm{~s}$. SHE). These values are higher than those in the present work which might be attributed to the fact that a lower $\mathrm{pH}$ was used by Morancho $(\mathrm{pH}=-0.7)$. 
Alloca et al. /16/ reported corrosion potentials of MOCVD-TiC in $0.1 \mathrm{~N} \mathrm{H}_{2} \mathrm{SO}_{4}$ of 300 to $400 \mathrm{mV}$ (vs. SCE). They reported only a slight difference between values in aerated solutions and solutions deaerated by bubbling purified nitrogen into the system. Since titanium and its divalent ion easily oxidises and there is always a small amount of oxygen left in the solution after deaeration with either water aspiration or nitrogen purge the "true" value of the corrosion potential of TiC in deaerated solutions might be very hard to measure. The first active peak of our experiments at $800 \mathrm{mV}$ ( $v s$. SCE) is not detected by the authors which might be a result of the high scanning rate, $111 \mathrm{mV} / \mathrm{min}$, compared with $6 \mathrm{mV} / \mathrm{min}$ in the present work.

Beverskog et al. $/ 7 /$ performed corrosion measurements on TiC which had been deposited onto quartz by activated reactive evaporation (ARE). The polarization curves were recorded with the same experimental set-up as in the present work. There is only one active peak in the diagram and at a lower value than for the CVD TiC $(710 \mathrm{mV}$ vs. SCE). At approximately $1800 \mathrm{mV}$ (vs. SCE) there is a slight current increase which might indicate the oxidation of $\mathrm{TiO}_{2} \cdot \mathrm{H}_{2} \mathrm{O}$ to $\mathrm{TiO}_{3} \cdot 2 \mathrm{H}_{2} \mathrm{O}$ as shown in eq.4. The ARE TiC evidently passivates easier, as shown by the lower values of passivation potential and also by the fact that the second passivation peak is only implied. Values of critical current density and passivation current density $\left(60 \mu \mathrm{A} \cdot \mathrm{cm}_{-2}\right.$ and $25 \mu \mathrm{A} \cdot \mathrm{cm}_{-2}$ respectively) agree well with values in the present work.

\section{CONCLUSIONS}

The inherent corrosion properties of hot wall CVD TiC, deposited at 1020 to $1080^{\circ} \mathrm{C}$ on polished and unpolished $\mathrm{Al}_{2} \mathrm{O}_{3}$ have been determined. Corrosion potentials in $1 \mathrm{M} \mathrm{HCl}$ varied between -100 and $350 \mathrm{mV}$ (vS. SCE). When recording the polarization curve two current density peaks, at 800 and $1800 \mathrm{mV}$ (vs. SCE), respectively, could be registered. It is presumed that the first peak corresponds to the oxidation of $\mathrm{Ti}^{2+}$ to $\mathrm{Ti}^{3+}$ which then immediately reacts to form $\mathrm{TiO}_{2} \cdot \mathrm{H}_{2} \mathrm{O}$ (see /13/). The second peak is due to the oxidation of $\mathrm{TiO}_{2} \cdot \mathrm{H}_{2} \mathrm{O}$ to $\mathrm{TiO}_{3} \cdot 2 \mathrm{H}_{2} \mathrm{O}$. Critical current density $\left(i_{c c}\right)$ for the first active peak ranges from 30 to $570 \mu \mathrm{A} \cdot \mathrm{cm}^{-2}$ and passive current density $\left(i_{p}\right)$ lies between 2 and $47 \mu \mathrm{A} \cdot \mathrm{cm}^{-2}$. For the second peak $i_{c c}$ is 1 to $7 \mathrm{~mA} \cdot \mathrm{cm}^{-2}$ and $i_{p}$ varies between 25 and $190 \mu \mathrm{A} \cdot \mathrm{cm}^{-2}$. The TiC showed no tendency to transpassive corrosion ( $<6 \mathrm{~V} v s$. SCE) and had a high oxygen overpotential $(>5 \mathrm{~V})$.

Potential-time curves of the uncorroded samples show discrepancies between the batches. TiC deposited onto polished $\mathrm{Al}_{2} \mathrm{O}_{3}$ (C samples) show rising potentials which stabilize, at about 250 $\mathrm{mV}$ (vs. SCE), after about one hour. TiC deposited onto unpolished $\mathrm{Al}_{2} \mathrm{O}_{3}$ ( $\mathrm{A}$ and $\mathrm{B}$ samples), on the other hand, have unstable corrosion potentials up to three hours, where they reach stable values of -100 to $0 \mathrm{mV}$ ( $v S$. SCE). This discrepancy between the samples is explained by a more protective oxide film on the $C$ samples.

\section{ACKNOWLEDGEMENTS}

Financial support from the Swedish Natural Science Research Council and the Swedish Board for Technical Development is gratefully acknowledged.

\section{References}

11/ HINTERMANN H E, Tribol. Int., 13(1980)267.

12/ RAMAEKERS P P J, VAN LOO F J J and METSELAAR R in CARLSSON $\mathrm{J}-O$ and LINDSTRÖM J (ed.),Proc. 5th Europ. Conf. CVD, (1985)354.

13/ NICKL J J, REICHLE M and RÜDIGER V in GLASKI F A (ed.), Proc. 3rd Int. Conf. CVD, (1972)369.

14/ KINBARA A, BABA S and MATUDA N, Thin Solids Films, 141(1986)229. 
15/ HINTERMANN H E, GASS $\mathrm{H}$ and LINDSTRÖM $\mathrm{J} \mathrm{N}$ in GLASKI FA (ed.), Proc. 3rd Int. Cont. CVD, (1972)352.

16/ HINTERMANN H E, RIDDIFORD A C, COWLING R D and MALYSZKO J, Elektrodepos. Surf. Treat., 1(1972)59.

17/ BEVERSKOG B, CARLSSON J -O, DELBLANC BAUER A, DESHPANDEY C V, DOERR H J, BUNSHAH R F and O'BRIEN B P: Surf. Coat. Technol., 41(1990)221.

18/ STORMS E K, The Refractory Carbides (Academic Press, New York, 1967).

19/ LINDSTRÖM J N and AMBERG $S$ in WAKEFIELD G F (ed.), Proc. 4th Int. Conf. CVD, (1973)115.

/10/ MORANCHO R, PETIT J A, DABOSI F and CONSTANT G, J. Electrochem. Soc., 12(1982)854.

111/ EVANS U R, J. Chem. Soc., 131:1(1929)92.

/12/ BANNISTER L C and EVANS U R, J. Chem. Soc., 132:1(1930)1361.

113/ SKORCHELETTI V V, Theory of Metal Corrosion (Keterpress Enterprises, Jerusalem, 1976).

/14/ BEVERSKOG B and CARLSSON J-O, Uppsala University Institute of Chemistry Series, B18-228.

115/ HINTERMANN H E and COWLING R D in GLASKI F A (ed.), Proc. 3rd Int. Conf. CVD, (1972)404.

116/ ALLOCA C M, WILLIAMS W S and KALOYEROS A E, J. Electrochem. Soc., 134(1987)3170. 